\title{
Report of the Annual Meeting
}

Rapports annuels de la Société historique du Canada

\section{A Dilemma for Our Culture}

\section{Presidential Address}

\section{Arthur Maheux}

Volume 28, numéro 1, 1949

URI : https://id.erudit.org/iderudit/300302ar

DOI : https://doi.org/10.7202/300302ar

Aller au sommaire du numéro

Éditeur(s)

The Canadian Historical Association/La Société historique du Canada

ISSN

0317-0594 (imprimé)

1712-9095 (numérique)

Découvrir la revue

Citer ce document

Maheux, A. (1949). A Dilemma for Our Culture: Presidential Address. Report of the Annual Meeting / Rapports annuels de la Société historique du Canada, 28(1), 1-6. https://doi.org/10.7202/300302ar

All rights reserved @ The Canadian Historical Association/La Société historique du Canada, 1949
Ce document est protégé par la loi sur le droit d'auteur. L’utilisation des services d'Érudit (y compris la reproduction) est assujettie à sa politique d'utilisation que vous pouvez consulter en ligne.

https://apropos.erudit.org/fr/usagers/politique-dutilisation/ 


\section{A DILEMMA FOR OUR CULTURE}

\section{Presidential Address by Abbé Arthur Maheux Laval Universily}

To talk culture has become fashionable. Books and periodicals are full of that subject. Anthropologists, sociologists, historians, have dug deeply into the strata of human culture. The research work has gone so far that the meaning of the word "culture" has been widened to include, not only the higher forms of civilization, but also the humblest kinds of culture found in the remotest parts of the earth. Learned men like Toynbee, to mention only one, have produced large works with culture as their central theme. These books do not mention "Canadian culture." Yet there is, or at least there will be, a Canadian culture. That is our main problem today.

Canada is made up of two principal groups-one of French origin, the other of British origin. France and England, at the time the settlers and immigrants came to America, were the foremost representatives of western culture. They already had a literature and works of fine art; they were beginning to observe nature and to find laws for natural phenomena; they had evolved a social structure of high quality; and they were prepared to go much farther along cultural lines. In government, France and Great Britain had evolved from their medieval condition to become "nations," to be what we usually call "modern nations." They had been at war for long periods, and little by little their differences had been deliberately accentuated, mainly on the cultural level.

Derived from these two nations, the settlers of New France, and later of Canada, preserved in America the same opinions about cultural differences as had existed in Europe. As they participated, even in America, in wars declared and waged in Europe for European reasons, the French and the English settlers continued to believe that they were fundamentally different on all scores. In the French-Canadian schools, the history that was taught was that of Mother France. In the EnglishCanadian schools it was that of Mother England. The greatest part of school text-books was devoted to wars between the two countries. School children were taught that France and Great Britain had always been enemies; they were made to believe that the cultures of these two nations were different, opposed, irreconcilable.

Little by little Canadians came to think that there were reasons for teaching something of the history of the country in which they lived. It was called "History of Canada," and also "National" history. It was mainly a branch of the history of the two Mother Countries with wars the central theme. The idea of "nation "pervaded it, just as one might have expected. The French Revolution, the research work of the Germans, the insularity of Britain, all these had developed the phenomenon called nationalism. The teaching of history became nationalist, a glorification of one nation, a demonstration that that nation was the best, the greatest, and the most superior. Our text-books in Canadian history have followed those trends for a long time. They have been nationalist text-books. They have imbued the young with the idea that the French and English in Canada are widely separated along cultural lines. 
In this way we have created a wall between the two main Canadian groups. The barrier of language was already high enough in itself to separate them. Emphasis on the wars between the two European Mother Countries and between their immigrants in America made that barrier still higher. Instruction in literature, the arts, and religion tended to have the same effect. Up to now we have thus insisted, in both Canadian groups, on emphasizing and re-emphasizing the differences between us.

The question is this: Have we been right?

The first answer to the question is that at least we have had excuse. We have done just what other nations have done. It is quite natural for youngsters to imitate grown ups and to conform to the general rules. We did not know at the time what would become of Canada. We did not think that some day our country would come of age. We were colonials, just colonials, and glad to leave to the Mother Country most of the heavy responsibilities of mature nations. Yes, we can be excused. But making excuses does not solve our problem. For a problem has been created with our natural evolution towards adulthood, and also with the changes that have taken place in the world. We want to be a nation. We dream of being a large nation. We feel that we must become a strong nation.

One condition for being a large and strong nation is unity. We realize that a certain amount of unity is essential to our ambitions. Yet in the past, we have done practically everything to create or to perpetuate divisions between the two main groups of our country. The situation occupied by Ganada in world affairs makes it imperative that she should be able to give advice and to offer solutions when required. We must seek unity, the sort of unity that will be a living inspiration, a font pouring clear water, a spring that will uplift our own national life and even the life of the world. Such a conception of unity is necessarily of a very high order.

We cannot reach that high standard unless we change our views on many subjects, unless we revise our opinions about our origins, about our development, about our cultural needs. We must pay due respect to our ancestors, for all their accomplishments, but we must also be brave enough to blame them for their faults and deficiencies. Shall we, as our ancestors did, believe that, as French and English, we are different races, different cultural units, fatally bound to be enemies? No, we cannot believe that.

From the point of view of race we are exactly the same. None of us can claim to be a pure race. All of us, French or English, come from a mixture of Celts, Romans, Germans, Northmen. Most of us can trace our ancestry to Normans. As racial products, we are all on the same level, let that level be high or low. That truth must be taught as early as possible to our children, in the family circle and at school.

If we are not different by blood, is it on account of culture? Here again the answer is no. French and English belong to the same culture, are both children of western civilization. Culturally we have eaten of the same food, a food that was a mixture of Roman laws and Roman public administration, of Greek and Roman literature, arts, and philosophy, of Christian religion, of the classical spirit of the Renaissance, of modern techniques, of the love of liberty, of the democratic form of 
government, of the same social experiments, of the same scientific discoveries. That, also, must be taught early to our youth in the family circle and in school. There have been wars between France and England. For a long time these wars were "dynastic" wars, in which the kings of the two countries would fight about a marriage, or for the socalled point of honour, or even for some small piece of territory. In such wars, the people of France and England were not enemies; they fought because the king wanted to fight. Later came the "imperialistic" wars. In this case the responsibility fell on the state, on the government, on the ministers of the crown, on certain hotheads, but not on the people of either country. The common peoples, the middle classes of France and England were not enemies. In spite of dynastic ambitions, in spite of imperialist dreams, the two nations could and did shake hands across the Channel. Writers, novelists, poets, dramatists, philosophers, scientists, entered into friendly relations by an exchange of letters and visits. They influenced each other. Their only quarrel, if such it can be called, was as to who was the first to have made a discovery or to have invented a chemical formula.

Nothing of that is ever told the school children, and yet that is the real history of the two countries. From that point of view our textbooks must be severely revised. We must no longer teach the history of France in Quebec and the history of England outside Quebec, but we must everywhere in Canada teach the history of western civilization as it has developed both in England and in France. Other western nations should not be excluded, of course, particularly Spain, Portugal, and the Netherlands, which had many contacts with the Americas, and also Belgium, Italy, Switzerland, Germany, Scandinavia, and the rest. A window should be open towards the orthodox nations-Greece, the Balkans, Russia, and her satellites. At a higher educational level, Asiatic nations would come in, since our civilization must learn to meet theirs. With such teaching, Canadians would be well prepared to accept the idea of a world government, which seems to have become a necessity. These studies, by constant comparison, would give to young Canadians a much better idea of the value of western civilization, and would also give a much broader view of our own Canadian problems.

These problems must be studied from a lofty point of vantage. The approach would be not the consideration of an English or a French heritage, but of Canada as the recipient of a universal cultural tradition. Both British and French cultures have equal value as starting points for such a treatment of our civilization. My contention is that they are neither inimical nor opposed; they are simply different in some ways; different enough to be interesting; different enough and valuable enough to be retained and to be worked out for the common good.

Two Canadians of English language have clearly explained these differences. One is Richard M. Saunders, professor of history at the University of Toronto, in his booklet, The French-Canadian Outlook. The other is A. R. M. Lower, of Queen's University, in his book, Colony to Nation. One Canadian of French language, Esdras Minville, has made an equally valuable contribution in his book, Le Citoyen CanadienFrançais. Those who would care to read these books could form a very good idea about the differences between the two main Canadian groups. The readers would even understand that the differences are not irrecon- 
cilable. To have reached that level of understanding is already a long step towards the solution of our cultural dilemma.

Others also have worked at that problem. In the twenties of this century some of our public men began to realize that a compromise was possible between our two cultures, and that we could work them out towards national unity. Two names are important for that period: Moore, with his volume, The Clash, and Morley, with his book, Bridging the Chasm. Other writers followed their example so that recently we had the books of Wilfred Bovey, Canadien; of Margaret McWilliams, This New Canada; of Vincent Massey, On Being Canadian. Jean Bruchési's recent book, Canada, réalités d'hier et d'aujourd'hui, has also much to contribute to the study of relations between the two Canadian groups. The translation of some of these works into French has been very popular in Quebec.

Many Canadians think that the main difference lies in language. I consider that that is a great exaggeration. All Canadians can become sufficiently familiar with the other language to read newspapers, magazines, and books. Many Canadians can go further and learn enough of the other language to deal with each other in the affairs of ordinary life. In that field we have made long strides during recent years. The Canadians of French language have set the example of bilingualism, not only through necessity in trade, industry, and professional activity, but also with the sincere desire of meeting their fellow citizens half way. Canadians of the English language have answered the challenge by learning French. The French courses organized for teachers by the Universities of Toronto, of Western Ontario, and of McGill are already famous. Two other English-Canadian universities, that of Alberta at Edmonton and of Queen's at Kingston, offer summer courses, the first in conversational French at Banff, the last in conversational English for French Canadians. The Department of English Protestant Education in the Province of Quebec deserves special mention; under the initiative and supervision of Dr. Percival, the study of the French language in Quebec has been reorganized on a very special basis. A society born in Toronto under a French name, Les Visites Interprovinciales, has had an excellent influence by arranging the exchange of young men and women between Ontario and Quebec. In all these cases the aim is primarily to learn the other language, but it is also to study the way of life of the other group. The new generation of young Canadians will be more nearly bilingual. In a certain measure it will also be bi-cultural.

Another main difference between the two groups is laid to religion; but there is much doubt and discussion on that subject. In my opinion such discussions should be left to specialists, who in this case are the theologians. There are too many people who, with very little knowledge of religious doctrines, want to impose upon others their personal beliefs. For my part it has always been a pleasure to discuss religious difficulties with educated people, who can appraise the real scope of religious problems. I really think, with many prominent Canadians, that the difference of religion is not the major difficulty in Canada, or at least that it should not be so. As it is still, in some places, a burning question, I shall not say more about it.

A greater difficulty or difference is to be found in the philosophy of life. Dr. Lower and M. Minville have dealt extensively with that prob- 
lem in their books. In my opinion it is the greatest difference, though it is less well known than the others. Philosophy is not taught in the same way in French Catholic universities and in English Protestant universities. It would take too long and would be out of place here to enter into details on that subject. Scholastic philosophy is as much expounded in the French-Canadian universities as it is neglected or even despised in the English-Canadian universities. The difference is particularly important in the social and political field, in economics, and in general ethics. Even if we spoke exactly the same language, the words would not have the same meaning and a discussion would be practically impossible. I do not say that the French-Catholic universities have no regard for modern philosophy, since they teach it also, but I consider it is a pity that so little attention is given to scholastic philosophy in the English-Canadian institutions.

Literature, of course, is different in the two groups, as a result of the difference of language. Yet the difficulty may be overcome either through bilingualism or by translation. We should have an office of translation, well established and well organized, so that the most significant books could be translated as soon as they appear.

Both cultures in Canada have their merits and they can contribute to the well-being of the country. They can exert their influence separately, as has been done up to now, but they can also work jointly. If they united their forces the result might be tremendous. If we want to achieve that union, it will be necessary to make serious changes in our teaching. The French-Canadian student will have to learn more about British institutions, politics, and literature. On the other hand the English-Canadian student should study more of the French form of civilization. Both groups should closely scrutinize the development of both cultures in the American environment. We should not try to imitate France or England or even the United States; on the contrary we should borrow from those countries the best they can offer and apply it to our situation. We must also dare to devise something new, that would be our personal contribution either to the welfare of our country or to that of the world at large.

This seems to me the only way of breaking our cultural dilemma. It is impossible to uproot the French culture that has been implanted in the American soil. That culture is rich and fertile, it is eminently usable for practical purposes. Consequently all Canadians should imbibe it in schools of all degrees.

I have not yet mentioned the teaching of history, though it is a very important aspect of our cultural problem. There have been many discussions about that. Some have advocated what they call "Federal Education." That can be only a dream, since no province will ever give up its right in that field. Others have urged a single text-book throughout Canada; that also is very difficult to realize, though it is not impossible. But the best means to ensure a sound teaching of history is to entrust that teaching to teachers who have received a university degree in history. History is a science; it is taught as a science in our departments of history. Doctors and masters in history would give to their students a scientific and factual training, instead of a course in civics or even in propaganda, provided, however, that in our departments of history, an equal importance be given to both civilizations, the French 
and the British. Otherwise there would be no equilibrium and the same old divisions and quarrels would remain forever.

I have imposed upon your patience a rather long series of personal opinions. Their only merit is that of sincerity and the fact that they are the result of a long study of the cultural problem in Canada. I offer them for what they are worth and I thank you for your attention.

Now you will permit me to turn for a moment to the French-speaking audience.

Je viens de mentionner la présence d'auditeurs de langue française. Dans l'espèce, il s'agit bien, sans doute, des Acadiens, et aussi des Français de France ou des îles françaises et enfin des auditeurs anglophones qui savent le français. Je suis sûr qu'il leur sera à tous agréable d'entendre résonner le verbe français en cette occasion. La naissance d'Halifax il y a deux siècles ne comportait rien d'amical pour l'élément français. C'était un avant-poste britannique dressé comme une épée au flanc de l'Empire français en Amérique. C'est d'ici que sont parties les flottes qui ont renversé Louisbourg et emporté Québec. Mais le temps a passé; il a atténué les oppositions, il a émoussé les épines; il a remis les épées au fourreau.

Acadiens, vous êtes revenus après une douloureuse dispersion, sur ce sol que vous avez été les premiers à cultiver. Dès avec Lescarbot vous avez apporté ici la culture française et vous n'avez pas voulu la laisser mourir. Sa flamme, un moment vacillante, s'est rallumée. Aujourd'hui vous avez en Nouvelle-Écosse votre université française et le Nouveau-Brunswick en a deux. La bienfaisance de ces trois institutions n'est pas contestable. Ici même à l'université de Dalhousie, vous trouvez un enseignement français, confié à des hommes toujours bien choisis. Pour ne mentionner qu'un nom je rappelerai parmi les professeurs d'autrefois, ce M. Ernest Martin, dont l'apostolat par l'enseignement et le livre a tant fait pour raviver dans le Canada oriental la flamme de la civilisation française. Ajoutons l'oeuvre des Pères Eudistes et les efforts de votre clergé acadien.

Gardez votre foi dans les vertus de la culture française. C'est à vous qu'il appartient de démontrer que cette culture peut servir les intérêts du Canada. Vous avez reçu de vos aïeux un précieux héritage. Grardezle et faites le valoir, pour le bien de tous.

The city of Halifax possesses a third element, the Irish Catholics. I cannot refrain from sending to them my personal homage and that of the Canadian Historical Association. They have done their share for the prosperity of this city. They also have their own cultural treasure to put at the service of the country. Finally, let me in my own name and in the name of our Association offer to the whole population of the city of Halifax and its civic and religious authorities the best wishes for the future. 